DOI: $10.17516 / 1997-1370-0740$

УДК $81-114.2$

\title{
Categoricalness in Scientific Discourse
}

\author{
Nadezhda N. Panchenko a and Yana A. Volkovab* \\ ${ }^{a}$ Volgograd State Socio-Pedagogical University \\ Volgograd, Russian Federation \\ ${ }^{b}$ People's Friendship University of Russia (RUDN University) \\ Moscow, Russian Federation
}

Received 23.05.2020, received in revised form 31.01.2021, accepted 08.04.2021

\begin{abstract}
The article views categoricalness as a communicative category functioning in the scientific discourse and adversely affecting the process of scientific communication. The results of the discourse and contextual analysis of categoricalness revealed its correlation with the communicative categories of politeness, authoritativeness, confidence, subjectivity, and emotionality. The analysis of the texts of scientific reviews, oral discussions, and disputes allowed the authors to conclude that Russian scientific communication is characterized by a high level of categoricalness, which suggests potential conflictogenity in such type of interaction. The article discusses ways of neutralizing categoricalness through the use of several mitigation tools, including lexico-stylistic and syntactical ones, intended to eliminate the destructive component from scientific communication.
\end{abstract}

Keywords: categoricalness, destructiveness, credibility, authoritativeness, emotionality, communication, communicative category.

Research area: philology.

Citation: Panchenko, N.N., Volkova, Ya.A. (2021). Categoricalness in scientific discourse. J. Sib. Fed. Univ. Humanit. Soc. Sci., 14(4), 535-543. DOI: 10.17516/1997-1370-0740.

(C) Siberian Federal University. All rights reserved

* Corresponding author E-mail address: panchnn@yandex.ru, yana.a.volkova@gmail.com

ORCID: 0000-0003-4498-5262 (Panchenko); 0000-0003-1456-5881 (Volkova) 


\title{
Категоричность в научном дискурсе
}

\author{
Н.Н. Панченко , Я.А. Волковаб \\ ${ }^{a}$ Волгоградский государственный \\ соииально-педагогический университет \\ Российская Федерачия, Волгоград \\ ${ }^{6}$ Российский университет дружбьы народов (РУДН) \\ Российская Федерачия, Москва
}

\begin{abstract}
Аннотация. На примере научного дискурса авторы рассматривают категоричность как коммуникативную категорию, оказывающую влияние на характер протекания коммуникативного научного взаимодействия. Результаты дискурсивного и контекстуального анализа реализации категоричности позволили выявить ее взаимосвязь с категориями вежливости, авторитетности, уверенности, субъективности, эмоциональности. Благодаря анализу примеров научных рецензий и устных научных дискуссий в исследовании сделан вывод о том, что русскоязычной научной коммуникации свойствен высокий уровень категоричности, что обусловливает потенциальную конфликтогенность подобного взаимодействия. В статье предлагаются пути и способы нейтрализации категоричности с помощью ряда митигативных средств, что призвано способствовать конструктивному научному общению.
\end{abstract}

Ключевые слова: категоричность, деструктивность, достоверность, авторитетность, эмоциональность, коммуникация, коммуникативная категория.

Научная специальность: 10.00 .00 - филологические науки.

\section{Introduction}

Nowadays, studies into communicative categories are gaining popularity, which allows deeper understanding of the mechanisms and principles of communication. Communicative categories, diverse in their communicative nature, structure, and functional significance, are believed to affect the effectiveness of communication. In our opinion, one of the communicative categories found in various types of discourse and determining its pragmatics is categoricalness.

Since communicative categories as elements of communicative consciousness have not been thoroughly studied so far, the analysis of their implementation and functioning allows us to talk about the theoretical significance and scientific novelty of the presented study. We also believe that the manifestation of categoricalness in scientific discourse, characterized by non-categoricalness, generality, evidentiality, accuracy and clarity
(Cherniavskaia, 2005), is of particular interest.

The purpose of this article is to explore the distribution and function of the communicative category of categoricalness in scientific discourse as well as to identify possible ways of reducing or avoiding it. It needs to be stressed that the paper presents the exploratory stage of our current research. The working hypothesis can be formulated as follows: in scientific discourse, categoricalness is intentional in nature; it is associated with the destructive strategy of the speaker, focused on downplaying the authority of the scientific opponent by demonstrating his/her superiority.

\section{Categoricalness:}

\section{Background and the Use of the Term}

One cannot ignore the fact that the phenomenon of categoricalness attracts researchers of various paradigms of knowledge in human sciences, such as philosophy, psy- 
chology, sociology, and, of course, linguistics.

From a philosophical point of view, categoricalness is interpreted as an unconditional statement or negation that excludes an alternative, thus appearing as a category identical to lack of alternatives (Kont-Sponvil', 2012). In this regard, one cannot help recalling Kant's categorical imperative, which functions as a moral law, unconditional, not recognizing excuses, an absolute requirement and compulsion to moral actions.

The psychological paradigm of knowledge interprets categoricalness as non-admittance of another opinion and defines it as straightforwardness and frankness, confidence in one's words and actions, the reasons for such outwardly manifested confidence being often found in internal psychological problems, primarily, deep self-distrust.

In sociology, categoricalness is again associated with a high degree of the speaker's confidence, motivated and partly justified by his/her high social status. "By acquiring a status, an individual masters the roles that correspond to him, carrying out this process through the prism of his personal social and emotional experience, and also under the influence of the environment to which he belongs" (Topka, Koneva, 2015: 176). According to the authors, in the space of institutional discourse, the situation of demand, because of the social status and the corresponding right of the speaker to categorical speech actions, is often associated with situations of order and accusation (ibid.), which is inevitably manifested in the decisive demand for unconditional, unquestioning execution of orders.

In linguistics, categoricalness is defined through semantically related concepts, which allows us to recreate its "semantic portrait": категоричный - безапелляционный, безусловный, догматичный, императивный, конкретный, не допускающий/не терпящий возражений/иного понимания/иных толкований, однозначный, решительный, твердый, ультимативный (peremptory, unconditional, dogmatic, imperative, specific, not allowing/not tolerating objections/other opinions/other interpretations, unambiguous, de- cisive, firm, ultimatum) (Aleksandrova, 2011; Ushakov, 2000).

Thus, we can see that all approaches to categoricalness in human sciences associate it with a kind of unconditional position intolerant to other opinions. To explore its role in scientific discourse, we need to answer the following questions: How does categoricalness function in discourses? What language means are involved in its implementation? These aspects will be considered in the next chapter.

\section{Categoricalness in Discourse}

As we have already mentioned, categoricalness is one of the communicative categories that are directly oriented to the communication process and affect the nature of communicative interaction. Regarding its functioning, categoricalness performs communicative-organizing and regulatory functions. We believe that categoricalness can be detected in various discourses, both institutional and non-institutional, its evaluative perception being different. While in a status-oriented discourse, categoricalness is generally expected and justified, and, therefore, is not openly condemned, in personality-oriented communication, categorical communicative behaviour does not receive an unambiguous definition.

Categoricalness is not always assessed positively; it is commonly perceived negatively. Suffice it to observe the above-mentioned synonymous concepts through which categoricalness is interpreted. First of all, the negative perception is connected with the fact that a categorical person who practices "blackand-white" thinking has binary logic based on two-value options, unquestionably positive and unquestionably negative. Such unambiguity, intolerance to a different understanding, the "inflexibility" of the speaker cannot but cause protest, rejection of such behaviour by the communication partner. The categorical speech behaviour of a person is characterized by the absence of doubts about what has been said, and intemperance in assessments. The speaker's confidence in his/her knowledge, assessments, statements, etc. determines the direct connection of the category in question with another 
category of communicative interaction - reliability/credibility.

One cannot fail to notice that categoricalness is directly related to the category of emotionality, since in communicative behaviour it manifests itself as an open demonstration of disregard for the opinions of others, a manifestation of inflexibility, superiority or disrespect.

In communication, categoricalness is recognized through several verbal and non-verbal markers. First of all, it can be identified through the explicit means of expression:

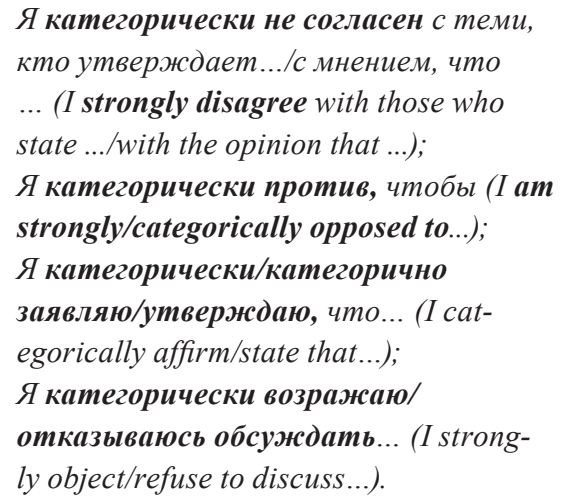

Note that the predominant use of the "I"-construction strengthens the meaning of reliability, but fails to tune the interlocutor into constructive interaction.

Among the non-verbal markers that allow us to identify categoricalness, the prosodic components of communication dominate, with the authoritative tone being the most frequent one (категоричным тоном распорядилась/ констатировал/сказал (ordered/said/confirmed in a categorical tone)):

И вот пришел новый начальник $u$ сухим, категоричным тоном объявил, что никаких машин нет и не предвидится. (And so the new chief came and in a dry, categorical tone announced that there were no cars and not any was expected) (Yu. Trifonov. Quenching thirst. RNC)

Categoricalness can also be recognized with the help of directive speech acts, discursive strategies and tactics of the speaker. Performing a regulatory function, categoricalness correlates with the speaker's choice of a particular strategy and tactics of communica- tive behaviour. It is no coincidence that some researchers pay attention to the influencing potential of categoricalness, defining it "as a tactical technique used by communication participants to achieve a specific impact goal" (Topka, Koneva, 2015).

Thus, being connected with the categories of persuasiveness and emotionality, categoricalness directly affects the nature of the communicative interaction; it can create a tense atmosphere of communication, and sometimes lead to an acute conflict situation, which means that categorical communicative behaviour may be considered a variety of destructive communication.

There is little doubt that categoricalness as an obligatory communicative category can be found in any type of discourse - personal (common) and institutional (political, mass media, pedagogical, medical, etc.) discourses.

In the next chapter, we will turn to the manifestation of categoricalness in scientific discourse, and try to answer the question of how common categoricalness is for this type of discourse and whether it is possible to talk about the destructive potential of categoricalness in relation to scientific communicative interaction.

\section{The Analysis of Categoricalness in Scientific Discourse}

\subsection{Features of Scientific Discourse}

First of all, we should remember that the main communicative canons of scientific discourse traditionally include accurate and logical presentation, reasoned validity or invalidity of certain provisions. The scientific style is distinguished by its purpose to objectively demonstrate the truth, empirical conclusiveness supported by confirmed relevant arguments. Since scientific discourse is considered a tool and a means of perceiving reality and storing scientific knowledge, it fulfills a number of functions, namely communicative, cognitive, and accumulative.

A scientific text is a product of a goal-oriented communicative activity: many scientists sometimes work on the same scientific problem, including researchers from different countries who often have opposite points of view. 
Among other things, scientific discourse aims to demonstrate the correctness or fallacy of theories, concepts, opinions, etc. The participants of the scientific communicative interaction who enter into a scientific polemic dialogue are scientists deemed equal in the communication process. This equality exists because "none of the researchers has a monopoly on truth, and the infiniteness of knowledge makes each scientist critical about both his/her own and others' research" (Karasik, 2000).

In other words, there are many parameters characteristic of scientific discourse. They include the academic style of speech, relevance and authoritativeness. While the scientific style categories (accuracy, abstractiveness, logic, objectivity) have been described in detail (see the papers by Ponomareva, 2004; Rakitina, 2006; Cherniavskaia, 2005; Banks and Di Martino, 2019), a few words should be said about authoritativeness as a communicative category of scientific discourse, since it directly correlates with the category of categoricalness.

It is widely recognized that authoritativeness belongs to the core characteristics of scientific discourse and is revealed in scientific texts through a number of discourse markers of direct and indirect authoritativeness, which include references to the authority of the work's author, public opinion, the viewpoint of recognized specialists in this field of science; impersonality of presentation in combination with focusing on the achievements of the author; the use of complex special terminology in this area of research; appeal to illustrative examples, etc. (Boldyreva, 2006: 4). Therefore, the hypothetical nature of scientific theories and principles should supposedly stimulate the non-categorical tonality of scientific interaction, and it is quite reasonable that the principles of scientific communication include the principles of cooperation and politeness with their main maxims (G.P. Grice, D. Leech) designed to neutralize possible conflict situations. However, the use of the above-mentioned discourse markers to prove and defend their point of view often requires imperative modality, which is one of the discourse manifestations of categoricalness. Categoricalness, therefore, comes into conflict with the norms of scientific communication, violating research ethics.

Interestingly, the survey of foreign research papers on scientific discourse did not reveal any mentioning of caterogicalness as its meaningful feature. In one respect, this might be the evidence of the low priority of this category for the western academic community; but this might also be because this category is inherently present in some mitigating/downtoning techniques known as "hedging".

\subsection{The Specifics of Categoricalness in Scientific Discourse}

The variety of genres of scientific discourse, as you know, can hardly be reduced to a single foundation, with the possible criteria for classifying genres being tasks that are implemented by the author of a scientific text, the volume and structure of the text, the channel of communication (oral or written).

Without setting ourselves the task of differentiating scientific genres and types of scientific texts, we would like to draw attention to those situations of scientific interaction that are directed at polemics and/or scientific dialogue, in which coincidences or discrepancies in the assessment of the problems under discussion can be identified. It is in such cases that categoricalness is most vividly manifested.

Let us discuss a few contexts. The first one is an extract from a letter which is a response of a Deputy Director for Research at a university Master's program to a student's request to help with the research theme. The extralinguistic factors are as follows: the author of the request is an extra-mural student, a practising school teacher, i.e. an adult with a certain social status; the object of the discussion is the theme of scientific research involving a comparative analysis of the educational systems of Russia and the United Kingdom.

Выл могли поступить в
общепедагогическую магистратуру
и анализировать и сколько угодно
сравнивать даже системь образования
Древней Греции, современного Китая и
Англии времен Чосера, но Вы выбрали
магистерскую программу "Современные


технологии преподавания английского языка».

<..> Магистерская программа направлена на подготовку квалифицированных преподавателейпрактиков в области технологий преподавания английского языка, а не теоретиков-мечтателей.

$<\ldots>$ Если у Вас с Вашим научным руководителем другое видение, обрамайтесь с ним лично к директору. Я лично не усматриваю прямой связи названной Вами темы ВКР с магистерской программой.

You could have enrolled at the Master's program in general pedagogy and analyze and compare even educational systems in Ancient Greece, modern China and England in the times of Chaucer as much as you like, but you have chosen the "Modern Technologies in Teaching English” Master's program.

$<\ldots>$ This program is aimed at training qualified practising teachers in the field of English teaching technologies, not dreamer theorists.

$<\ldots>$ If you and your supervisor have a different vision, contact the director personally. I do not see any direct connection between the theme of the qualification paper you mentioned and the Master's program.

In this example, several categorical devices can be observed: the use of sarcastic speech technique, the repeated use of the second-person pronoun $\mathrm{Bbl}$ (You), which indicates the direction of the statement at the addressee and emphasizes the unconditional character, the confidence of the addressee in his/her assessment; using the imperative which makes any statement sound categorical. All of the above does not leave the addressee an opportunity to discuss or defend his/her position (in this example, the research theme). The categorical statements here are a sign of disrespect and superiority; they initially put the communicants in an unequal position. In this example, it does not matter who is right; it is important that the addressee feels that his/her opinion is disrespected, which prepares him/her for further rejection of communication with a person whose job responsibilities include consulting on academic and research issues. This example also indicates a possible connection of categoricalness with the communicative category of destructiveness because the intention to humiliate the addressee can be observed. It should be noted that this letter also has an indirect addressee, the supervisor of the Master's student, who is also "curbed" by being sent to the head of the institute. Thus, in this example, the categorical nature of the statement translates the everyday situation of scientific communication into conflict communication, which often has neither interpersonal nor scientific value.

The argument "This is not linguistics!" sounds approximately in the same vein when discussing topics, papers and messages not related to the study of the language system proper. To illustrate this point, we provide a fragment from a discussion of a scientific presentation at a linguistic conference (Volgograd, 2019). One of the participants (doctor of philology) addresses the question "What do you mean by discourse?" to the speaker (candidate of philology). After a detailed explanation that included references to some distinguished linguists (N.D. Arutiunova, V.I. Karasik, etc.), the author categorically declares: "For me, discourse is not a linguistic concept," demonstrating peremptoriness and, we dare say, a kind of sciolism. Therefore, the categorical nature of the statement eliminates the possibility of scientific discussion and, unfortunately, inhibits the initiative and development of scientific thought.

Categorical manifestations in written scientific works can be illustrated by the example of scientific reviews, thesis report reviews and extended abstract reviews. These scientific genres comply with the norms of scientific ethics and ideally tend towards an indirect expression of negative assessments and are thereby oriented towards non-categorical opinions (Nefedov, 2019).

Не могу согласиться с А.Д.Н. и в том, что существует прямой способ выражения угрозы. На мой взгляд (который я изложила в своей статье...). And I cannot agree with A.D.N. that there is a direct way of expressing threat. In my opinion (which I outlined in my article ...) 
We do not intend to discuss the fallacy of the reviewer's position here (though, phrases like "I'll smack your face/I'll punch you" do sound like direct ways of expressing threat). In this passage, the author of an extended abstract review, a researcher with a doctor's degree, resorts to an authoritarian method of assessing the young researcher's work, which stimulates categoricalness.

T.V. Larina draws attention to the categorical language of Russian scientific reviews: "As a rule, such means of mitigation are absent in Russian-language reviews. Instead, we encounter impersonal value judgments that often include language means of imperative modality, which gives the style of Russian reviews a categorical tone: The presented article requires a serious revision" (Larina, 2019: 391).

The genre of scientific review, which aims at evaluating scientific research, is characterized by the highest density of evaluative language units. "The review compares two individual pictures of the world, two worldviews and meanings" (Khomutova, Kravtsova, 2014: 72). At the same time, the reviewer is focused on his own "I", his ideas and views often presented in a categorical form:

Почти анекдотически выглядит список литературы $\kappa$ статье O.H. Кондратьевой.

The list of references to the article by O.N. Kondratieva looks almost anecdotal (Review // Voprosy yazykoznaniya, 2008, No. 4) .

Despite the use of the de-intensifier nочти ("almost"), the lexeme "anecdotal", which bears a sharp negative evaluative connotation, forms an unambiguously critical attitude towards the author of the publication.

In the following example, the reviewer's opinion is presented as the only and objectively existing truth, while not only the scientific views of the author of the dissertation are subject to direct negative criticism, but the author himself, though indirectly:

Остается загадкой, как, например, автору удалось совместить взгляды Г.И. Богина и В.И. Карасика, М.М. Бахтина и Н.Д. Арутюновой, и т.д. <..> и не мудрено: в рамках заявленной «когнитивной» парадигмы это просто невозможно (Pishchal'nikova).

It remains a mystery, how, for example, the author managed to combine the views of G.I. Bogin and V.I. Karasik, M.M. Bakhtin and N.D. Arutyunova, etc. <..> And no wonder: within the framework of the declared "cognitive" paradigm, this is simply impossible (Pishchal'nikova).

\subsection{Ways to Downtone Categoricalness}

In this chapter, we will attempt to answer the question: What are the possible ways to mitigate categoricalness in scientific discourse?

To downtone categoricalness, tactics of mitigating the negative evaluation and harshness of critical remarks can be used. They derive from the politeness principles and aim at creating a friendly tone of communication, maintaining a communicative balance, both your own and your opponent's "face". As a rule, this can be achieved through the use of a variety of mitigative language means (Takhtarova, 2010), which include lexical units indicating the subjectivity of a critical remark (по моему мнению, на наш взгляд, как нам представляется/видится (in my opinion, in our opinion, it seems/is viewed)) as well as de-intensifiers (не вполне, почти, слегка (quite, almost, slightly)). "To implement evaluative mitigation, meiotic signs can be used; they include euphemisms, meiotisms and litotes proper, whose common pragmatic orientation towards optimizing" (Takhtarova, 2010).

In the western practice of teaching academic and scientific style, there is a special section on teaching hedging, a set of special techniques for mitigating categorical statements, the so-called "academic political correctness" (Plappert, 2019). Hedging practices, including the use of non-imperative modality, impersonal and passive constructions, a set of lexical indicators of the degree of certainty, various stylistic and rhetorical techniques, are included in most textbooks on academic English and are vital components of academic discourse (see, for example, Oliver del Olmo, 2015). In the examples below, one can observe some hedg- 
ing techniques: modal words and words with a modal meaning as well as modal verbs with a meaning of uncertainty:

On the one hand, the depiction of Aegisthus as teacher-tyrant in Agamemnon seems to reveal an aristocratic perspective similar to that seen elsewhere in archaic and classical Greek 'song culture,' in particular Pindaric lyric - and presumably reveals an audience receptive to this perspective (Rogers, 2005: 188189).

While we might take comfort in the fact that no one doubts PV belongs to the fifth-century $B C$, the possibility that the play could belong to the second, third, or even perhaps final quarter of the fifth century BC affects the kind of argument we can make with PV (Rogers, 2005: 202).

In these fragments, the use of hedging techniques does not only soften but, in fact, eliminates categoricalness from the text by minimizing the author's responsibility for the expressed point of view and providing a space for discussion on the issue under discussion.

Unfortunately, techniques of mitigating categoricalness in Russian scientific discourse are not taught to undergraduate and graduate students (although there are a number of dissertations on categoricalness in various discourses, see: Malyshkin, 2015; Mariukhin, 2010; Takhtarova, 2010), and young scientists have to learn from their own mistakes (for example, when foreign journals reject their articles precisely because of the author's categorical style). The last point makes the issue of categoricalness in a scientific discourse especially relevant: this communicative category should be subjected to detailed study with subsequent development of practical recommendations for researchers on the ethics of working with scientific text (writing and reviewing scientific papers) as well as holding scientific debates.

\section{Conclusions}

Categoricalness in scientific discourse is intentional and functions as a specific speaker's strategy aimed at demonstrating his/her self-righteousness, superiority and often at discrediting the opponent's opinions.

In the analyzed examples of scientific polemics, different variants of categorical communicative behaviour functioning through verbal and non-verbal cues are presented. It seems that categoricalness as a category of communicative interaction is directly related to the categories of reliability, emotionality, persuasiveness and authoritativeness. The basis of the analyzed examples of categorical communicative behaviour in Russian scientific discourse is the general authoritative strategy, which has enormous destructive potential and thereby contributes to disregarding the partner in scientific dialogue.

Categoricalness can be reduced with the help of a number of mitigative means, including hedging techniques, which contributes to constructive scientific communication. Nevertheless, some observations suggest that the use and functioning of mitigative devices in scientific discourse can be culture-specific and should therefore be considered in a wide cultural context.

\section{References}

Aleksandrova, Z.E. (2011). Slovar' sinonimov russkogo yazyka. Prakticheskyi spravochnik [The dictionary of Russian language synonyms. A practical guide]. Available at: http://dic.academic.ru/contents.nsf/ dic_synonims/(accessed 10 September 2019).

Banks, D., Di Martino, E. (2019). Introduction: Linguistic and discourse issues in contemporary scientific communication. Aspects of communicating science to a variety of audiences. In Journal of Pragmatics, 139, 185-189.

Boldyreva, A.A. (2006). Kategoriia avtoritetnosti v nauchnom diskurse [The category of authority in scientific discourse]. Abstract of the candidate's thesis, Voronezh, $19 \mathrm{p}$.

Cherniavskaia V.E. (2005). Interpretatsiia nauchnogo teksta [Interpretation of scientific text]. Moscow, KomKniga, 127 p. 
Karasik, V.I. (2000). O tipakh diskursa [About the types of discourse]. In Iazykovaia lichnost': institutsional'nye i personal'nye diskursy [Language personality: institutional and personal discourse], 5-20.

Khomutova, T.N., Kravtsova E.V. (2014). Nauchnaia retsenziia: integral'nyi podkhod [Scientific review: integral approach]. In Iazyk i kul'tura [Language and culture], 70-76.

Kont-Sponvil', A. (2012). Filosofskyi slovar' [Philosophical dictionary]. Available at: http://philosophy_sponville.academic.ru/ (accessed 15 September 2019).

Larina, T.V. (2019). Emotsii i vezhlivost' v stile anonimnoy nauchnoy retsenzii [Emotions and politeness in the style of an anonymous scientific review]. In Sbornik nauchnykh statey Mezhdunarodnoy Konferentsii "Nastoiashchee i budushchee stilistiki" [Proc. Int. Conf. "Present and future of stylistics"]. Moscow, 387- 394.

Malyshkin, K.Iu. (2015). Kategorichnost' kak semantiko-pragmaticheskaia kategoriia vyskazyvania (na materiale sovremennogo russkogo iazyka) [Categoricalness as a semantic and pragmatic category of utterance (based on modern Russian language)]. Candidate's thesis, Omsk, 204 p.

Mariukhin, A.P. (2010). Nepriamaia kommunikatsiia v nauchnom diskurse: na materiale russkogo, angliyskogo, nemetskogo iazykov [Indirect communication in scientific discourse: based on Russian, English, and German languages]. Candidate's thesis, Moscow, $166 \mathrm{p}$.

Nefedov, S.T. (2019). Towards evaluation in scientific reviews (based on German linguistics). In Journal of Siberian Federal University. Humanities \& Social Sciences, 10 (2019 12), 1868-1886.

Oliver del Olmo, S. (2015). Academic writing in English L2: From student's learning tasks to 21 $1^{\text {st }}$-century professional practices. In ICERI2015: 8TH International Conference of Education, Research and Innovation. Chova, LG; Martinez, AL; Torres, IC. (Eds). Seville, SPAIN, 7014-7023.

Plappert, G. (2019). Not hedging but implying: identifying epistemic implicature through a corpus-driven approach to scientific discourse. In Journal of Pragmatics, 139, 169-174.

Ponomareva, E.N. (2004). Nauchnyi stil' kak ob'ekt osvoeniia nositeliami iazyka [Scientific style as an object of learning by native speakers]. Abstract of the candidate's thesis, Tomsk, $24 \mathrm{p}$.

Rakitina, S.V. (2006). Nauchnyi tekst: kognitivno-diskursivnye aspekty [Scientific text: cognitive-discursive aspects]. Volgograd, Peremena, $278 \mathrm{p}$.

Rogers, B. (2005). Before Paideia: Representations of education in Aeschylean tragedy. A dissertation submitted to the Department of Classics and the Committee on Graduate Studies of Stanford University in partial fulfillment of the requirements for the Degree of Doctor of Philosophy. Stanford University.

Takhtarova, S.S. (2010). Kategoriia kommunikativnogo smiagcheniia: kognitivno-diskursivnye i etnokul'turnye aspekty [Category of communicative mitigation: cognitive-discursive and ethno-cultural aspects]. Doctoral thesis, Volgograd, $430 \mathrm{p}$.

Topka, L.V., Koneva V.F. (2015). Sotsial'naia obuslovlennost' kategorichnogo rechevogo povedeniia [Social conditionality of categorical speech behaviour], In Filologicheskie nauki. Voprosy teorii i praktiki [Philological science. Questions of theory and practice]. 7 (49), 174-178.

Ushakov, D.N. (2000). Tolkovyi slovar' russkogo iazyka: V 4 t. [Explanatory dictionary of the Russian language: In 4 vols.]. Vol. 1. Moscow, Izdatel'stvo Astrel', Izdatel'stvo AST, 1562 p. 